\title{
LEGITIMASI SYARIAH TERHADAP NILAI WAKTU UANG
}

\author{
Ahmad Ali Sopian", \\ Ekonomi Islam, UIN Sunan Gunung Djati Bandung \\ email: aalsopian24@gmail.com
}

\begin{abstract}
ABSTRAK
Nilai waktu uang pada sistem ekonomi konvensional dipandang bahwa uang bukan hanya berfungsi sebagai alat tukar (medium of exchange) dan kesatuan hitung (unit of account) tetapi juga berfungsi sebagai komoditas yang dapat diperjualbelikan hingga menghasilkan keuntungan.berdasarkan hal tersebut, uang dipandang memiliki nilai waktu (time value of money) bila di simpan dalam waktu tertentu yang diproksi dengan tingkat bunga. Dalam perspektif ekonomi Islam bunga dipandang sebagai hal yang haram. fatwa DSN MUI sebagai Legitimasi syariah atau pengakuan hukum pada tindakan kegiatan lembaga keuangan syariah membuat garis yang kontras dalam memandang uang dalam sistem ekonomi konvensional dan uang dalam tatan ekonomi islam. Metodologi yang digunakan untuk menelaah atau sebagai pisau analisis pada tulisan ini adalah studi kepustakaan atau studi literatur. Dimana studi literatur difokuskan pada artikel atau tulisan-tulisan yang telah ada sebelumnya. Berdasarkan hasil studi tersebut diperoleh kesimpulan bahwa Ekonomi Islam memandang bahwa uang hanya berfungsi sebagai alat tukar (medium of exchange) dan kesatuan hitung (unit of account) tidak sebagai komoditas. Uang tidak dapat diperjualbelikan dan dispekulasikan secara bebas. Dan uang tidak memiliki nilai waktu, tetapi waktulah yang memiliki nilai ekonomis (economic value of time). Dalam ekonomi islam keuntungan pada transaksi keungan didasarkan pada aspek bagi hasil berbeda dengan ekonomi konvensional yang berbasis bunga.
\end{abstract}

\section{Kata kunci: uang, nilai, bunga bank,}

\begin{abstract}
The time value of money in the conventional economic system is seen that money not only functions as a medium of exchange and a unit of account but also functions as a commodity that can be bought and sold to generate profits. Based on this, money is seen as having value. time (time value of money) if it is stored in a certain time which is proxied by the interest rate. In the perspective of Islamic economics, interest is seen as haram. MUI's DSN fatwa as sharia legitimacy or legal recognition of the activities of Islamic financial institutions makes a contrasting line in viewing money in the conventional economic system and money in the Islamic economic system. The methodology used to examine or as a knife of analysis in this paper is literature study or literature study. Where literature studies are focused on articles or writings that have been there before. Based on the results of this study, it is concluded that Islamic economics views that money only functions as a medium of exchange and the unit of account is not a commodity. Money cannot be traded and speculated freely. And money has a time value, but the time may have economic value (economic value oftime. In the Islamic economic advantage on the financial transaction based on the different aspects of the results with conventional interest-based economy.
\end{abstract}

Keywords: money, value, interest bank 


\section{PENDAHULUAN}

Uang merupakan instrumen perekonomian yang sangat penting. Hampir semua kegiatan ekonomi sangat bergantung pada instrumen ini yang antara lain, berfungsi sebagai alat tukar ataupun alat bayar. Dengan demikian kehadiran uang dalam kehidupan sehari-hari menjadi vital, terutama untuk memperoleh barang, jasa, serta kebutuhan hidup lainnya. Uang merupakan inovasi modern yang menggantikan posisi barter, atau tukar menukar satu barang dengan barang lainnya. Di samping itu terhapusnya sistem pertukaran barter dalam sejarah ekonomi bangsa tidak terjadi dalam waktu yang sama. walaupun pertukaran atau barter mengalami penurunan tajam setelah uang mengambil alih fungsi sebagai alat tukar perdagangan internasional, namun pertukaran barter kini banyak dilihat sebagai alternatif yang bagus dalam perdagangan antar negara. ${ }^{1}$

Pengaruh perkembangan teknologi dan informasi terhadap perekonomian dunia semakin berkembang dengan perluasan pasar serta peningkatan produktivitas. Sistem perekonomian kini bergesr dari sistem perekonomian yang traditional pada sistem perekonomian modern yang lebih efektif dan efisien. Dengan semakin kompleksnya perdagangan dan spesialisasi berdampak pula pada perubahan bentuk alat tukar yang dapat memudahkan transaksi. Uang sebagai alat untuk mempermudah terjadinya transaksi, dengan menjadikannya sebagai alat pertukaran barang dan jasa dalam suatu wilayah. Dalam persfektif hukum positif, uang merupakan segala sesuatu yang dirumuskan undang-undang yang dapat berfungsi sebagai alat tukar. Dengan demikian uang menjadi alat pemba-

\footnotetext{
${ }^{1}$ Sepri Wulan Sari, "Perkembangan Dan Pemikiran Uang Dari Masa Ke Masa," An-Nisbah: Jurnal Ekonomi Syariah 3, no. 1 (2016).
}

yaran dalam memudahkan terjadinya pertukaran barang dan jasa, sehingga semua aktivitas ekonomi dapat dijalankan dengan lebih mudah².

Tingkat nilai uang berbeda waktu sering dihubungkan oleh tingkat diskonto yang didasarkan pada bunga. Terori yang dibangun bahwa tingkat bunga yang positif menimbulkan nilai uang saat ini yang lebih berharga dari pada pada saat nanti. Serta tingginya tingkat bunga yang relevan, dapat menimbulkan pada semakin besarnya perbedaan antara nilai uang yang diterima saat ini dibanding dengan nilai uang yang akan diterima dikemudian hari. Sistem ekonomi dalam konvensional yaitu konsep nilai waktu uang yang memiliki pengaruh signifikan dalam pengelolaan berbagai aktivitas ekonomi. Konsep tersebut dipandang berpengaruh terhadap berbagai keputusan dan teknik keuangan, seperti keputusan investasi (penganggaran modal), biaya modal, struktur modal, penilaian sekuritas seperti saham dan obligasi, perhitungan amortisasi hutang, kebijakan dividen, dan lain-lainnya.

Tinjauan legitimasi syariah terhadap nilai waktu uang pada sistem ekonomi konvensional memunculkan garis pemisah yang kontras terhadap sistem ekonomi islam. ekonomi Islam yang melakukan aktivitas ekonomi yang sama tetapi dalam sistem yang diterapkan memiliki prinsip dan sumber hukum yang berbeda dengan ekonomi konvensional. Segala aktivitas yang dilakukan dalam aktifitas ekonomi Islam bersumber pada hukum

${ }^{2}$ Rini Elvira, "Pandangan Ekonomi Islam Terhadap Nilai Waktu Uang," Fakultas Syari'ah dan Ekonomi Islam IAIN Bengkulu (2014), https://ejournal.iain bengkulu.ac.id/index.php/mizani/article/download/55/ 55. 
Islam, yakni Al-Qur'an, hadis dan ijma ulama, dalam hal ini fatwa ${ }^{3}$.

Perkembangan Lembaga Keuangan Syariah terus menunjukkan kinerja yang menakjubkan. Berbagai indikator keuangan seperti total nilai aset dan jumlah dana pihak ketiga juga terus mengalami peningkatan. Pertumbuhan Lembaga Keuangan Syariah di Indonesia tidak terlepas dari peningkatan tingkat kepercayaan masyarakat untuk mengakses jasa layanan Lembaga Keuangan Syariah. Hal ini memberikan gambaran bahwa keberadaan kantor Lembaga Keuangan Syariah dan unit-unit pembiayaan syariah yang tersebar di hampir seluruh wilayah tanah air hingga ke pelosok. Pada transaksi Lembaga Keuangan Syariah tidak menempatkan uang sebagai komoditas perdagangan, dan tidak menetapkan suku bunga dalam transaksi karena riba, tidak ada unsur time value of money. Balas jasa atas penggunaan dana dalam Lembaga Keuangan Syariah menerapkan prinsip bagi hasil ${ }^{4}$.

\section{Metodologi}

Metodologi yang digunakan dalam tulisan ini adalah studi literatur, dimana studi literaur atau studi kepustakaan merupakan telaah yang dilakukan hanya berdasarkan atas karya tertulis, termasuk hasil penelitian baik yang telah maupun yang belum dipublikasikan. Mnurut Melfianora studi Literatur atau studi kepustakaan dan studi pustaka/riset pustaka meski bisa dikatakan

${ }^{3}$ Misbahul Khoir, "Nilai Waktu Dari Uang Dalam Perspektif Ekonomi Islam," JES (Jurnal Ekonomi Syariah) 1, no. 1 (September 5, 2016), accessed November 12, 2020, http://jes.unisla.ac.id/index.php/jes/article/ view/6.

${ }^{4}$ Maltuf Fitri, "Prinsip Kesyariahan Dalam Pembiayaan Syariah," Economica: Jurnal Ekonomi Islam 6, no. 1 (May 4, 2016): 57, accessed November 12, 2020, https://journal.walisongo.ac.id/index.php/economica/a rticle/view/786. mirip akan tetapi berbeda. Studi pustaka adalah istilah lain dari kajian pustaka, tinjauan pustaka, kajian teoritis, landasan teori, telaah pusaka (literature review), dan tinjauan teoritis. ${ }^{5}$

\section{HASIL DAN PEMBAHASAN}

\section{Definisi Legitimasi}

Legitimasi dipandang sebagai suatu penerimaan dan pengakuan masyarakat terhadap hak moral pemimpin untuk memerintah, membuat dan melaksanakan keputusan politik. Legitimasi ini juga dipandang sebagai bagian dari kewenangan, dan kewenangan merupakan bagian dari kekuasaan. Legitimasi ini dapat terbentuk dengan berbagai cara yang mampu dikelompokkan dalam tiga kategori yakni secara simbolis, prosedural atau material. Berdasarkan cara dan sumber perolehan tersebut maka munculah beberapa jenis legitimasi yaitu legitimasi tradisional, legitimasi ideologi, legitimasi kualitas pribadi, legitimasi prosedural serta legitimasi instrumental. Sedangkan Syariah diartikan secara istilah sebagai suatu sistem atau aturan yang mengatur kehidupan manusia dalam beribadah baik secara hubungan antara manusia dengan Allah, ataupun hubungan manusia dengan manusia secara fiqh dan muammalah ${ }^{6}$.

${ }^{5}$ Melfianora, "Penulisan Karya Tulis IImiah Dengan Studi Literatur," Open Science Framework (2019): 1-3, osf.io/efmc2.

${ }^{6}$ M.H.I. Dr. Moh. Mufid, Lc., "Kaidah Fiqh Ekonomi Syariah- Google Buku," last modified 2015, accessed November 12, 2020, https://books.google.co.id/ books? hl=id\&|r=\&id= IzUpDwAAQBAJ\&oi =fnd\& $\mathrm{pg}=\mathrm{PA} 6 \mathrm{dq}=$ fiqh+dan+syariah\&ots $=$ UaVQfkrhag \&sig=_Y4eUJ- DyvsJeaVjOR3-4VOmLKY\&redir_esc=y\#v= onepage $\& q=$ fiqh dan syariah $\& f=f a l s e$. 
Menurut pakar hukum dan hak azasi manusia, unsur-unsur Legitimasi diantaranya meliputi:
a. Dukungan untuk komunitas politik.

b. Dukungan untuk prinsip, norma, dan prosedur rezim inti.

c. Penilaian kinerja rezim.

d. Dukungan untuk institusi rezim.

e. Dukungan untuk pihak berwenang.

Berdasarkan pada unsur-unsur legitimasi diatas, maka jenis-jenis legitimasi pada hukum positif dibedakan menjadi:

\section{Legitimasi Politik}

Legitimasi politik ialah suatu gambaran dari politik yang berdasarkan pada suatu keputusan dari hasil peradilan yang memiliki tujuan sebagai suatu bukti bahwasanya pada setiap kebijakan yang sudah di tetapkan adalah unutk kepentingan masyarakat luas.

2. Legitimasi Hukum

Legitimasi hukum adalah pengakuan hukum yang terdapat di tengah masyarakat yang bisa di katakan ada kaitannya dengan tindakan perbuatan hukum yang berlaku serta berbagai undang-undang yang sah dan sudah di tetapkan.

3. Legitimasi Kekuasaan

Legitimasi Kekuasaan merupakan suatu keyakinan pada setiap anggota di dalam maysrakat yang mentaati serta menerima berbagai kebijakan yang sebelumnya telah di buat oleh penguasa dan telah memenuhi berbagai tuntutan yang ada pada Rezim penguasa tersebut.

Berdasarkan pada definisi legitimasi menurut hukum positif maka legitimasi hukum dipandang sebagai pengakuan hukum yang terdapat di tengah masyarakat yang bisa di katakan ada kaitannya dengan tindakan perbuatan hukum yang berlaku serta berbagai undang-undang yang sah dan sudah di tetapkan. Dengan demikian legitimasi syariah didefinisikan sebagai pengakuan hukum pada tindakan kegiatan berasaskan syariah yang sah. Dalam konteks syariah pada legitimasi nilai waktu uang dapat diukur dengan bersandar pada fatwa DSN MUI sebagai payung hukum pelaksanaan akad-akad mumalah pada lembaga keungan syariah.

\section{Konsep Nilai Waktu Uang (Time Value of Money)}

Sistem ekonomi konvensional mendefinisikan pengertian nilai waktu uang (time value of money) sebagai " A dollar today is worth more than a dollar in the future because a dollar today can be invested to get a return". pengertian ini mengandung arti bahwa uang saat ini selalu lebih berharga dibandingkan dengan uang pada saat yang akan datang, karena uang yang diterima pada saat ini akan dapat diinvestasikan untuk memperoleh hasil yang lebih besar dimasa yang akan datang. Konsep yang mendasari nilai waktu uang adalah nilai uang pada waktu yang berbeda tidaklah sama, artinya terjadinya perbedaan nilai uang saat ini dengan nilai uang di masadepan yang terjadi karena adanya unsur waktu. Faktor yang menghubungkan nilai waktu adalah tingkat diskonto yang diproksi dengan tingkat bunga. Konsep ini dikembangkan dari berbagai teori bunga (theory of interest), dari berbagai pandangan para ekonom kapitalis sepanjang masa. menurut classical theory of interest yang diungkapkan oleh adalah Adam Smith dan David Ricardo, menyatakan bahwa bunga merupakan kompensasi yang dibayarkan oleh peminjam (borrower) kepada si pemberi pinjaman (lender) sebagai balas jasa atas keuntungan yang diperoleh dari uang 
yang dipinjamkan. menurut Bohm Bawerk, pengembang teori bunga austrian, menyatakan bahwa orang akan merasa senang dengan barang yang ada sekarang dibandingkan barang yang akan diperoleh pada masa yang akan datang ${ }^{7}$.

Berdasarkan teori moneter konvensional diketahui bahwa pembayaran bunga merupakan tindakan opportuniti untuk memperoleh keuntungan dari meminjamkan uang. Keynes menyebutkan bahwa motif spekulasi dari permintaan akan uang (liquidity preference). Motif tersebut maknai sebagai usaha untuk menjamin keuntungan pada masa yang akan datang. Dengan demikian, menurut konsep nilai waktu uang mengambil bunga uang adalah logis sebagai ganti dari penurunan daya beli uang selama dipinjamkan.

Menurut Najmudin terdapat dua alasan utama yang mendasari munculnya konsep nilai waktu uang pada konsep ekonomi konvensional, diantaranya yaitu:

1) Presence of inflation,

Dengan memasukan tingkat inflasi dalam perekonomian. Dapat dimisalkan, misalnya saja tingkat inlasi sebesar $12 \%$ per tahun. Seseorang dapat membeli 11 unit komoditas pada hari ini hanya dengan membayar Rp.1.200.000,- (satu juta dua ratus ribu rupiah), namun bila ia membelinya tahun depan, dengan sejumlah uang yang sama yaitu Rp. 1.200.000,- (satu juta dua ratus ribu rupiah), maka ia hanya dapat membeli 9 unit komoditas yang sama. Dengan demikian, ia akan meminta kompensasi

7 S.H Remi, Prof. Dr. Sutan Remy Sjahdeini, Perbankan Syariah: Produk-Produknya Dan Aspek-Aspek Hukumnya (Jakarta: Kencana, 2014).

${ }^{8}$ Kasmir, Bank Dan Lembaga Keuangan Lainnya, Ed. Revisi (Jakarta: Rajawali Pers, 2008). untuk hilangnya daya beli uangnya akibat inflasi.

2) Preference present consumption to future consumption,

Pada pandangan kebanyakan personal, present consumption lebih disukai dibandingkan future consumption. misalnya jika tingkat inflasi samadengan nol, sehingga dengan uang Rp.1.200.000,- (satu juta dua ratus ribu rupiah) seseorang tetap dapat membeli 11 unit komoditas pada hari ini maupun pada tahun depan. Bagi kebanyakan orang, mengkonsumsi 11 unit komoditas saat ini lebih disenangi dibandingkan mengkonsumsi 11 unit komoditas pada tahun depan. Dengan alasan ini, walaupun tingkat inflasi nihil, Rp.1.200.000,-- (satu juta dua ratus ribu rupiah) lebih disukai dan dikonsumsi hari ini. Dengan demikian, untuk menunda konsumsi, ia mensyaratkan kompensasi ${ }^{9}$.

Menurut Veithzal Rivai masih terdapat dua alasan yang lain yang menjadi dasar munculnya konsep nilai waktu uang dalam konsep ekonomi konvensional, diantaranya yaitu:

1) Adanya aspek risiko (ketidakpastian) atas uang yang diterima dimasa datang.

Peristiwa atau kehidupan manusia dimasa datang bersifat tidak pasti, sedangkan uang yang diterima saat ini sangat jelas dan pasti.

2) Adanya opportunity cost (biaya kehilangan kesempatan)

Hal ini diasumsikan sebagai akibat yang terjadi karena tidak memiliki uang lebih awal untuk diinvestasikan.misalnya jika

\footnotetext{
${ }^{9}$ Najmudin, Manajemen Keuangan Dan Akuntansi Syariah (Yogyakarta: ANDI, 2011).
} 
uang tersebut diterima lebih awal, maka akan dapat digunakan untuk kegiatan investasi yang akan memungkinkan untuk mendapat keuntungan. tetapi karena terjadi penundaan penerimaan uang, maka tertundanya penerimaan uang diartikan sebagai kehilangan peluang untuk mendapatkan keuntungan, sehingga penundaan penerimaan uang menjadi dasar bagi pengenaan sejumlah uang tertentu untuk menutup kerugian karena kehilangan kesempatan untuk berinvestasi jika uang diterima pada waktu sekarang.

Sedangkan menurut Ahmad Ifham sedikitnya terdapat 3 (tiga) alasan yang mendasari mengapa uang hari ini lebih bernilai dibandingkan dengan uang di masa yang akan datang yaitu:

1) Uang kehilangan nilainya dari waktu ke waktu. Daya beli uang yang terus menerus jatuh terutama disebabkan oleh adanya inflasi dalam perekonomian yang dapat menurunkan daya beli terhadap suatu komoditas.

2) uang memiliki biaya kesempatan. Jika seorang memiliki uang hari ini, maka ia akan dapat menginvestasikan uang tersebut dalam beberapa usaha bisnis, dengan demikian akan meningkatkan jumlah uang seseorang di masa depan. Dalam analisis konvensional, pendapatan bunga merupakan salah satu biaya kesempatan dari uang.

3) ketidakpastian arus kas masa depan. Arus kas masa depan adalah harapan saja. Dengan demikian, arus kas masa depan tidak pasti dan berisiko. Orang menghargai arus kas sekarang karena lebih bernilai dibandingkan dari arus kas masa depan.

Menurut Ayub Nilai waktu uang dapat tinjau pula berdasarkan konsep bunga yang dijalankan pada sistem ekonomi konvensional. Tingkat bunga dalam sistem ekonomi konvensional terhadap adanya nilai waktu dari uang dapat mendorong investor mempunyai kesempatan menyimpan uang yang diterima sekarang dalam suatu bentuk investasi dan mendapatkan bunga (interest). Dengan adanya kepastian arus kas, tingkat bunga dapat digunakan untuk menyatakan nilai waktu dari uang. Tingkat bunga memungkinkan untuk menyesuaikan nilai arus kas yang diterima atau dibayarkan pada waktu tertentu ke suatu waktu yang berbeda. Tingkat bunga terbagi kepada dua

1) Tingkat bunga sederhana, (simple interest)

Merupakan bunga yang dibayarkan atau diterima berdasarkan pada nilai asli, atau nilai pokok, yang dipinjam atau dipinjamkan. Nilai mata uang dari tingkat bunga sederhana merupakan fungsi dari tiga variabel : jumlah uang yang dipinjam atau dipinjamkan atau nilai pokok, tingkat bunga per periode waktu dan jumlah periode waktu dimana nilai pokok tersebut dipinjam atau dipinjamkan.

2) Tingkat Bunga Majemuk (compound interest)

Merupakan bunga yang dibayarkan atau diterima dari suatu pinjaman (investasi) ditambahkan pada nilai pokoknya secara periodik. Menunjukkan bahwa bunga dari suatu pokok pinjaman juga akan dikenakan atau memperoleh bunga pada periode selanjutnya. Dengan demikian, bunga diterima dari bunga dan nilai pokok periode sebelumnya. Pengaruh penggunaan tingkat bunga majemuk terhadap nilai suatu investasi setelah melewati masa tertentu sangat besar 
bila dibandingkan dengan pengaruh yang ditimbulkan oleh tingkat bunga sederhana. Perbedaan besar antara pengaruh tingkat bunga sederhana dan majemuk ini disebabkan oleh pengaruh bunga-berbunga atau bunga majemuk tersebut. Konsep bunga majemuk dapat digunakan memecahkan berbagai masalah keuangan secara luas dalam ekonomi konvensional ${ }^{10}$

\section{Nilai Uang pada Sistem Ekonomi Islam}

Konsep uang pada ekonomi Islam berbeda dengan konsep uang pada ekonomi konvensional. Sistem ekonomi konvensional menganggap uang tidak hanya sebagai alat tukar namun juga berfungsi sebagai untuk memperoleh pendapatan. Sehingga dalam hal ini uang diartikan secara bolak balik, yaitu uang sebagai uang (alat tukar), dan uang sebagai modal (spekulasi). Pada sistem ekonomi Islam, konsep uang sangat jelas bahwa uang adalah uang. Pada ekonomi Islam uang hanya berfungsi dan diakui sebagai alat tukar (medium of exchange) dan sebagai kesatuan hitung (unit of account). Hal ini dipertegas dengan pendapat para ulama dan ilmuwan sosial Islam seperti Al Ghazali, Ibnu Taimiyah, Ibnu Khaldun, Ibnul Qayyim Al Jauziyyah, Ibnu Abidin yang menegaskan bahwa fungsi uang hanya sebagai alat tukar. Fungsi spekulasi pada pengertian Keynes tidak ada pada pandangan ekonomi Islam. Hal ini disebabkan pada ekonomi Islam uang itu sendiri tidak memberikan manfaat, tetapi fungsi uanglah yang akan memberikan kegunaan. Uang akan berguna jika ditukarkan dengan barang nyata atau jika dibelikan jasa. Hal ini disebabkan pada ekonomi Islam uang

10 Muhammad Ayub, Understanding Islamic Finance (Jakarta: PT Gramedia Pustaka Utama, 2009). tidak dapat dijadikan komoditas dan diperdagangkan ${ }^{11}$.

Pada konsep ekonomi Islam uang adalah milik masyarakat (public goods). Barangsiapa yang menimbun uang atau dibiarkan tidak produktif maka berarti mengurangi jumlah uang beredar yang dapat mengakibatkan tidak jalannya perekonomian. Jika seseorang sengaja menumpuk uangnya tidak dibelanjakan, sama artinya dengan menghalangi proses kelancaran jual beli. Penumpukan uang juga akan mendorong manusia kepada sifat tidak baik seperti rakus, tamak, malas, malas beramal. Oleh hal ini disebabkan itu Islam melarang penimbunan uang (harta), memonopoli uang (harta). ${ }^{12}$ Sebagaimana dijelaskan pada Al Quran pada surat At- Taubah 34-35

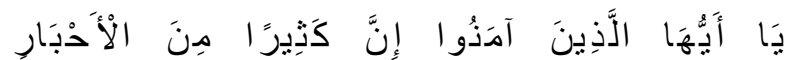

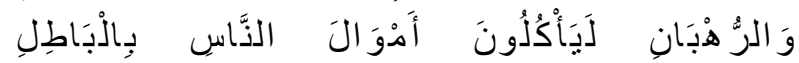

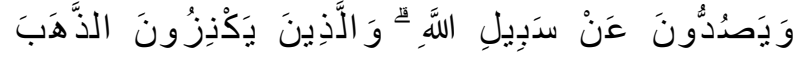

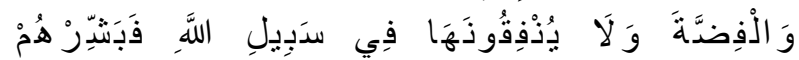

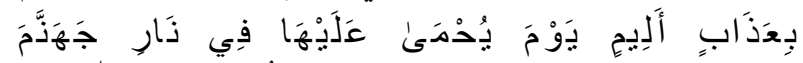

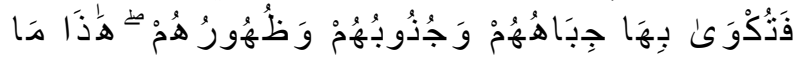

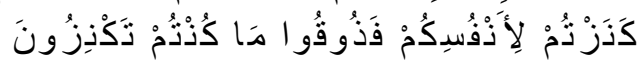

Hai orang-orang yang beriman, Sesungguhnya sebahagian besar dari orang-orang alim Yahudi dan rahib-rahib Nasrani benar-benar memakan harta orang dengan jalan batil dan mereka menghalang-halangi (manusia) dari jalan Allah. dan orang-orang yang menyimpan emas dan perak dan tidak menafkahkannya pada jalan Allah, Maka beritahukanlah kepada mereka, (bahwa mereka akan mendapat) siksa yang pedih. 35. Pada hari

11 Ressi Susanti, "Sejarah Transformasi Uang Dalam Islam," Aqlam: Journal of Islam and Plurality 2, no. 1 (February 1, 2018), accessed November 10, 2020, http://journal.iain-

manado.ac.id/index.php/AJIP/article/view/509.

12 Yunida Priyanti, “Uang Dan Nilai Waktu Dalam Islam," Al-Intaj : Jurnal Ekonomi dan Perbankan Syariah 3, no. 2 (September 20, 2017): 287-303, accessed November 12 , 2020, https://ejournal.iainbengkulu.ac.id/index.php/AlIntaj/article/view/2212. 
dipanaskan emas perak itu dalam neraka Jahannam, lalu dibakar dengannya dahi mereka, lambung dan punggung mereka (lalu dikatakan) kepada mereka: "Inilah harta bendamu yang kamu simpan untuk dirimu sendiri, Maka rasakanlah sekarang (akibat dari) apa yang kamu simpan itu." (Q.S. at Taubah: 34-35)

Berdasarkan keterangan pada ayat alQuran diatas, uang yang tidak produktif dalam artian kelebihan harta akan semakin berkurang karena adanya kewajiban zakat bagi umat Islam, oleh karena itu uang harus berputar. Islam menganjurkan bisnis (perdagangan), investasi di sektor riil. Uang yang berputar di sektor riil akan memberikan pendapatan bagi masyarakat banyak yang pada akhirnya akan meningkatkan daya beli mereka terhadap suatu komoditas.

Teori konvensional meyakini bahwa uang saat ini lebih bernilai dari pada uang pada masa depan. Teori ini berangkat dari pehamaman bahwa uang merupakan sesuatu yang berharga dan dapat berkembang dalam suatu waktu tertentu. Dengan memegang uang, orang akan dihadapkan pada risiko berkurangnya nilai uang karena inflasi, sementara jika uang disimpan dalam bentuk surat berharga maka akan mendapatkan keuntungan berupa bunga yang diperkirakan diatas inflasi yang terjadi. Namun teori nilai waktu uang ini tidak akurat karena kondisi ekonomi tidak selalu menghadapi inflasi, namun kadangkala kondisi ekonomi juga menghadapi deflasi. Munculnya deflasi akan menimbulkan preferensi waktu negatif diabaikan oleh teori ekonomi konvensional ${ }^{13}$.

Sementara itu, ekonomi Islam memandang waktulah yang memiliki nilai ekonomis

13 Fitri, "Prinsip Kesyariahan Dalam Pembiayaan Syariah." (penting). Pentingnya waktu disebutkan Allah, SWT dalam Q.S. Al-Ashr : 1-3:

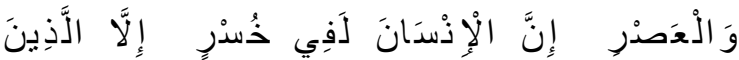

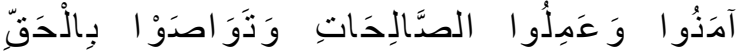

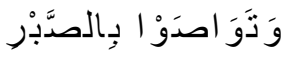

Demi masa, Sesungguhnya manusia itu benar-benar dalam kerugian, Kecuali orangorang yang beriman dan mengerjakan amal saleh dan nasehat menasehati supaya mentaati kebenaran dan nasehat menasehati supaya menetapi kesabaran (Q.S. Al-Ashr : 1-3)

Berdasarkan pemaparan diatas, maka dalam sistem ekonomi Islam, tidak terjadi konsep nilai waktu uang seperti yang uraikan dalam ekonomi konvensional. Jika bedasar pada surat al-Ashr ayat diatas dapat ditarik pemahaman bahwa setiap orang memiliki jumlah waktu yang sama secara kuantitas, tetapi yang membedakan adalah kualitasnya. Semua orang memiliki waktu 24 jam dalam sehari, namun nilai dari waktu itu akan berbeda dari satu orang dengan orang lain. Perbedaan nilai waktu tersebut adalah tergantung pada bagaimana seseorang memanfaatkan waktu. Semakin efektif dan efisien, maka akan semakin tinggi nilai waktunya. Efisiensi dan efektifitas waktu akan memberikan keuntungan lebih kepada orang yang melakukannya. Maka siapapun yang melakukannya akan memperoleh keuntungan di dunia dan akhirat apabila segala yang ia perbuat dengan niat beribadah kepada Allah SWT ${ }^{14}$.

Majelis Ulama Indonesia melalui fatwa Nomor 1 Tahun 2004 Tentang Bunga (interest atau fa'idah) memutuskan beberapa ketentuan, Pertama, Pengertian Bunga (Interest) dan Riba yang mencakup (a). Bunga (Interest atau fa'idah) adalah tambahan yang dikena-

14 Najmudin, Manajemen Keuangan Dan Akuntansi Syariah. 
kan dalam transaksi pinjaman uang (al-qard) yang diper- hitungkan dari pokok pinjaman tanpa mempertimbangkan pemanfaatan atau hasil pokok tersebut berdasarkan tempo waktu, diperhitungkan secara pasti di muka, dan pada umumnya berdasarkan persentase. (b). Ribh aadalah tambahan (ziyadah) tanpa imbalan yang terjadi karena penagguhan dalam pembayaran yang diperjanjikan sebelumnya, dan inilah yang disebut riba nasi'ah. Kedua, Hukum bunga (interest) yaitu, (a) Praktek pembungaan uang saat ini telah memenuhi kriteria riba yang terjadi pada zaman Rasulullah saw, yaitu riba nasi'ah. Dengan demikian, praktek pembungaan uang ini termasuk salah satu bentuk riba, dan riba haram hukumnya. (b) Praktek penggunaan tersebut hukumnya adalah haram, baik dilakukan oleh bank, asuransi, pasar modal, pegadaian, koperasi, dan lembaga keuangan lainnya maupun dilakukan oleh individu. Ketiga, Bermu'amalah dengan lembaga keuangan konvensional dengan ketentuan (a) Untuk wilayah yang sudah ada kantor dan jaringan lembaga keuangan syari'ah serta mudah dijangkau, tidak dibolehkan melakukan transaksi yang didasarkan kepada perhitungan bunga. (b) Untuk wilayah yang belum ada kantor atau jaringan lembaga keuangan Syari'ah, diperbolehkan melakukan kegiatan transaksi di lembaga keuangan konvensional berdasarkan prinsip darurat ${ }^{15}$.

Dalam Islam, keuntungan bukan saja keuntungan di dunia, namun yang dicari adalah keuntungan di dunia dan di akhirat. Oleh karena itu, pemanfaatan waktu bukan saja harus efektif dan efisien, namun juga harus didasari dengan keimanan. Keimanan inilah yang akan mendatangkan keuntungan di

15 Majelis Ulama Indonesia, "Himpunan Fatwa MUI Sejak 1975” (Jakarta: Erlangga Press, 2011). akhirat. Sebaliknya, keimanan yang tidak mampu mendatangkan keuntungan di dunia, berarti keimanan tersebut tidak diamalkan. Islam mengajarkan carilah keuntungan akhirat tapi jangan lupakan keuntungan dunia.

Sistem ekonomi Islam tidak dikenal dengan adanya permintaan uang untuk spekulasi karena uang bukanlah komoditas yang dapat diperdagangkan secara bebas. Ekonomi Islam juga tidak mengenal bunga, karena bunga sesungguhnya telah jatuh ke dalam kategori riba. Islam juga tidak mengenal konsep nilai waktu uang. Dalam pandangan Islam yang bernilai adalah waktu itu sendiri, nilai ekonomis waktu dan penghargaan Islam atas waktu tercermin dari banyaknya sumpah Allah yang terdapat dalam Alquran, yang menggunakan terminologi waktu. Misalnya demi masa, demi waktu dhuha, demi waktu fajar, demi waktu ashar, demi waktu malam dan masih banyak lagi. Dalam salah satu haditsnya, Rasulullah juga pernah bersabda, “Waktu itu seperti pedang, jika kita tidak bisa menggunakannya dengan baik, ia akan memotong kita.

Menurut Sayyid Qutb mengatakan, waktu adalah hidup. Namun penghargaan Islam terhadap waktu ini tidak diwujudkan dalam rupiah tertentu atau persentase bunga tetap. Karena hasil yang nyata dari pemanfaatan waktu ini bersifat variabel, tergantung pada jenis usaha, sektor industri, keadaan pasar stabilitas politik dan masih banyak lagi. Islam mewujudkan penghargaan pada waktu dalam bentuk kemitraan usaha dengan konsep bagi hasil. Oleh karena itu, menurut Islam uang tidaklah memiliki nilai waktu. Tetapi waktulah yang memiliki nilai ekonomi, tergantung bagaimana cara penggunaannya. Waktu akan memiliki nilai ekonomi jika waktu tersebut 
digunakan dengan baik dan bijak ${ }^{16}$. Selama manusia menggunakan waktunya untuk hal produktif tentunya waktu tersebut semakin bernilai, maka ada perbedaan nilai antara waktu seseorang dengan yang lainnya walaupun jumlahnya sama.

\section{Economic Value Of Time}

\section{pada Teori Pertukaran Syariah}

Teori pertukaran pada sistem ekonomi islam merupakan kontrak dalam bisnis yang memberikan kepastian pembayaran, baik dari segi jumlah maupun waktu. Penentuan harga jual beli dalam Islam dapat dirujuk dari fatwa Dewan Syariah Nasional (DSN) - Majelis Ulama Indonesia (MUI) No, 04/DSNMUI/IV/2001. yang menyatakan bahwa harga beli, Bank harus memberitahukan secara jujur harga barang kepada nasabahnya, berikut biaya yang diperlukan. Sedangkan pada harga jual, Bank harus menjual barangnya kepada nasabah, dengan harga jual senilai harga beli plus keuntungannya. Dalam dasar hukum penerapan akad murobahah yang di terapkan lembaga keuangan syariah juga mengacu pada Fatwa DSN No. 16/IX/2000 yang menyatakan: Harga dalam jual beli murabahah adalah harga beli dan biaya yang diperlukan ditambah keuntungan sesuai dengan kesepakatan ${ }^{17}$.

Pelaksanaan akad murabahah pada lembaga keuangan syariah dilakukan dengan mekanisme pembiayaan jual beli untuk produk pembiayaan yang bersifat konsumtif maupun produktif. Model akad murabahah ini umumnya diterapkan di industri perbakan syariah di Indonesia, karena itu akad mura-

16 Siti Mujibatun, "Konsep Uang Dalam Hadis" (2012).

17 Mudzzhar, M Atho, "Fatwa-Fatwa Majelis Ulama Indonesia: Sebuah Studi Tentang Pemikiran Hukum Islam Di Indonesia" (Jakarta: INIS Press, 1993). bahah termasuk akad pembiayaan yang menyerap porsi penyaluran dana paling dominan ketimbang akad pembiayaan lainnya. Salah satu fungsi pokok perbankan syariah adalah bertindak sebagai investor melalui mekanisme pembiayaan dengan skema akad jual beli murabahah, salam dan istisna', dan mekanisme investasi modal dengan skema akad mudarabah dan musyarakah.

Namun yang menjadi diskursus adalah penggunaan istilah pembiayaan dalam akad murabahah, sebagaimana tertuang dalam definisi akad murabahah pada UU No. 21 Tahun 2008 Tentang Perbankan Syariah, yaitu sebagai "akad pembiayaan suatu barang dengan menegaskan harga belinya kepada pembeli dan pembeli membayarnya dengan harga yang lebih sebagai keuntungan yang disepakati". Definisi yang berbeda dipaparkan dalam fatwa DSN-MUI tentang murabahah, yaitu sebagai menjual suatu barang dengan menegaskan harga belinya kepada pembeli dan pembeli membayarnya dengan harga yang lebih sebagai laba. Kerancuan istilah murabahah sebagai akad pembiayaan berdampak pada hubungan bank dengan nasabah sebagai hubungan kreditur dan debitur yang menimbulkan konsekuensi hukum terjadinya prestasi berupa penyerahan sejumlah uang dari pihak debitur kepada pihak kreditur dengan konsekwensi adanya imbalan sebagaimana tertuang dalam kontrak perjanjian. Perbedaan secara diametral ketika akad murabahah didefiniskan sebagai akad jual beli, maka konsekwensi hukum yang terjadi adalah pemenuhan hak dan kewajiban, yaitu penjual menyerahkan barang dan pembeli menyerahkan uang. Model transaksi ini menimbulkan dampak pertukaran financial aset berupa uang dengan riil aset berupa barang. Karena itu, margin keun- 
tungan yang diperoleh merupakan hasil akumulasi dari pengorbanan akan modal, resiko, dan kerja ${ }^{18}$.

Jual beli murabahah didasarkan atas kepemilikan sah dan penuh.Ketentuan umum dalam fatwa DSN-MUI Tentang Murabahah bahwa pihak bank harus membeli barang atas nama sendiri melalui proses jual beli yang sah dan bebas dari unsur riba. Kemudian menjual kepada nasabah dengan menyebutkan harga jual dan keuntungannya sebagaimana lazimnya proses jual beli murabahah. Konsep ini sesuai dengan pendapat mayoritas mazhab fikih aliran sunni, yaitu pihak penjual harus membeli barang dari pihak pertama dan barang itu dalam penguasaannya, kemudian menjual kepada pihak ketiga dengan harga pertama ditambah margin keuntungan disertai asas transparansi informasi, teknis pembayarannya dapat dilakukan dengan tunai maupun tangguh. Syarat ini termasuk salah satu syarat yang harus terpenuhi dalam obyek jual beli berdasarkan hadis Nabi saw: jual beli murabahah didasarkan atas akad amanah (kepercayaan) karena mensyaratkan penjual menjelaskan harga pertama tanpa didukung dengan bukti dan saksi. Karena itu, pembeli percaya terhadap penjual. Namun jika penjual tidak menjelaskan harga awal terhadap pembelian barang, maka akad murabahah menjadi batal ${ }^{19}$.

Pelaksanaan akad murabahah di industri perbankan syariah umumnya dimodifikasi untuk tuntutan fungsi perbankan sebagai lembaga keuangan. Karena itu hampir sulit

18 Atang Abd Hakim, "Fiqih Perbankan Syariah: Transformasi Fiqih Muamalah Ke Dalam Peraturan Perundang-Undangan" (Bandung: Refika Aditama Press, 2011).

19 Muhammad Amin Suma, "Himpunan UndangUndang Perdata Islam Dan Peraturan Pelaksana Lainnya Di Negara Hukum Indonesia" (Jakarta: PT. RajaGrafindo Persada Press, 2008). mengimplementasikan rukun jual beli secara sempurna. Yaitu bahwa obyek barang adalah milik sempurna bank sebelum melakukan transaksi jual beli secara murabahah kepada nasabah. Kenyataannya, bagi perbankan syariah yang kesulitan memenuhi syarat ini melakukan model murabahah dengan perwakilan (wakalah bil al-murabahah) seperti yang diterapkan bank Islam Dubai dengan istilah al-murabahah lilamir bi al-syira dan diikuti oleh lembaga keuangan syariah di indonesia untuk beberapa kasus tertentu.

Acuan implementasi modifikasi akad murabahah berdasarkan pada prinsip maqashid syariah, yaitu hifdz al-nafs dan hifdz almaal. Hifdz al-nafs diinternalisasikan sebagai bagian dari perwujudan setiap orang untuk bertahan hidup dengan melakukan kerjasama ekonomi dan saling membantu untuk mencapai keuntungan. Sedangkan hifdz al-maal diwujudkan dalam bentuk pengembangan kekayaan dalam kerjasama bisnis untuk menggapai profit. Pengembangan kekayaan mencegah tindakan yang dapat menimbulkan mudarat terhadap kekayaan, yaitu terjadinya penimbunan kekayaan dan ekonomi akan lesu, karena investasi modal tidak berjalan maksimal. Berikut ini merupakan pola perhitungan dalam menentukan harga pada lembaga keuangan syariah dengan penerapan akad murobahah ${ }^{20}$ :

Rumus:

$$
\mathrm{HI}=\mathbf{H B}+\left(\mathbf{t}^{*} \mathrm{CR}\right)+\mathbf{k}
$$

Keterangan :

$\mathrm{HI}=$ Harga Jual Bank merupakan harga yang disepakati antara penjual dengan (bank) pembeli (nasabah)

20 Remi, Prof. Dr. Sutan Remy Sjahdeini, Perbankan Syariah: Produk-Produknya Dan AspekAspek Hukumnya. 
$\mathrm{HB}=$ Harga Beli, adalah harga perolehan atau nilai pasar yang didapat bank saat membeli produk tertentu.

$\mathrm{t}=$ Waktu adalah periode yang digunakan untuk penyelesaian pembiayaan

$\mathrm{CR}=$ Cost Recovery adalah nilai biaya yang dikeluarkan bank untuk menyelesaikan pembiyaan.

$\mathrm{K}=$ Margi, adalah prosentase keuntungan yang diinginkan oleh penjual (bank) pada saat menjual produk pada pembeli (nasabah)

Sedangkan ruumus yang digunakan untuk menghitung harga jual produk dengan akan murobahah dengan pola nasabah memberikan uang muka, atau lembaga keuangan syariah memberikan potongan harga kepada nasabah adalah sebagai berikut:

$\mathrm{HI}=(\mathrm{HB}-\mathrm{UM})+\left(\mathrm{t}^{*} \mathrm{CR}\right)+\mathbf{k}$

Keterangan :

$\mathrm{HI}=$ Harga Jual Beli

$\mathrm{HB}=$ Harga Beli

$\mathrm{UM}=$ Uang muka nasabah

$\mathrm{T}=$ waktu

$\mathrm{CR}=$ Cost Recovery

$\mathrm{K}=$ margin keuntungan yang diinginkan.

\section{SIMPULAN}

Berdasarkan hasil paparan diatas maka dapat tarik kesimpulan terkait tinjaun legitimasi syariah terhadap nilai waktu uang adalah sebagai berikut:

Legitimasi syariah di definisikan sebagai pengakuan hukum pada tindakan kegiatan berasakan syariah yang syah. Dalam konteks syariah pada legitimasi nilai waktu uang dapat diukur dengan bersandar pada fatwa DSN MUI sebagai payung hukum pelaksanaan akad-akad mumalah pada lembaga keungan syariah.
Teori konvensional meyakini bahwa uang saat ini lebih bernilai dari pada uang pada masa depan. Teori ini berangkat dari pehamaman bahwa uang merupakan sesuatu yang berharga dan dapat berkembang dalam suatu waktu tertentu. Dengan memegang uang, orang akan dihadapkan pada risiko berkurangnya nilai uang karena inflasi, sementara jika uang disimpan dalam bentuk surat berharga maka akan mendapatkan keuntungan berupa bunga yang diperkirakan diatas inflasi yang terjadi. Namun teori nilai waktu uang ini tidak akurat karena kondisi ekonomi tidak selalu menghadapi inflasi, namun kadangkala kondisi ekonomi juga menghadapi deflasi. Munculnya deflasi akan menimbulkan preferensi waktu negatif diabaikan oleh teori ekonomi konvensional.

Dalam sistem ekonomi Islam uang berfungsi sebagai medium of exchange dan unit of account. Di samping itu uang juga sebagai komoditas. Dengan demikian uang tidak dapat diperjualbelikan dan dispekulasikan secara bebas. Hal ini disebabkan karena uang tidak memiliki nilai waktu (time value of time), tetapi waktu yang memiliki nilai ekonomis (economic value of time). Sehingga semakin efektif dan efisien dalam menggunakan waktu maka semakin besar nilai ekonomis waktu tersebut.

Jika pada ekonomi konvensional keuntungan di dasarkan pada penerapan bunga dalam setiap transaksi, sedangkan dalam sistem ekonomi islam perolehan keuntungan didasarkan pada akan bagi hasil dan tinajuan keuntungan bukan hanya pada objek materi dunia melainkan pada objek dunia dan akhirat. 


\section{DAFTAR PUSTAKA}

Dr Moh. Mufid, Lc., M.H.I. “Kaidah Fiqh Ekonomi Syariah - - Google Buku.” Last modified 2015. Accessed November 12, 2020. https://books.google.co.id/books?hl=id\&lr=\&id= lzUpDwAAQBAJ\&oi=fnd\&pg=PA6\&dq=fiqh+dan+syariah\&ots=UaVQfkrhag\&sig=_Y4 eUJ-DyvsJeaVj0R3-4V0mLKY\&redir_esc=y\#v=onepage\&q=fiqh dan syariah\&f=false.

Elvira, Rini. "Pandangan Ekonomi Islam Terhadap Nilai Waktu Uang." Fakultas Syari'ah dan Ekonomi Islam IAIN Bengkulu (2014). https://ejournal.iainbengkulu.ac.id/index.php/ mizani/article/download/55/55.

Hakim, Atang Abd. "Fiqih Perbankan Syariah: Transformasi Fiqih Muamalah Ke Dalam Peraturan Perundang-Undangan." Bandung: Refika Aditama Press, 2011.

Kasmir. Bank Dan Lembaga Keuangan Lainnya, Ed. Revisi. Jakarta: Rajawali Pers, 2008.

Khoir, Misbahul. “Nilai Waktu Dari Uang Dalam Perspektif Ekonomi Islam.” JES (Jurnal Ekonomi Syariah) 1, no. 1 (September 5, 2016). Accessed November 12, 2020. http://jes. unisla. ac.id/index.php/jes/article/view/6.

Majelis Ulama Indonesia. “Himpunan Fatwa MUI Sejak 1975.” Jakarta: Erlangga Press, 2011.

Melfianora. "Penulisan Karya Tulis Ilmiah Dengan Studi Literatur." Open Science Framework (2019): 1-3. osf.io/efmc2.

Mudzzhar, M Atho. “Fatwa-Fatwa Majelis Ulama Indonesia: Sebuah Studi Tentang Pemikiran Hukum Islam Di Indonesia." Jakarta: INIS Press, 1993.

Muhammad Ayub. Understanding Islamic Finance. Jakarta: PT Gramedia Pustaka Utama, 2009.

Mujibatun, Siti. “Konsep Uang Dalam Hadis” (2012).

Najmudin. Manajemen Keuangan Dan Akuntansi Syariah. Yogyakarta: ANDI, 2011.

Priyanti, Yunida. “Uang Dan Nilai Waktu Dalam Islam.” Al-Intaj : Jurnal Ekonomi dan Perbankan Syariah 3, no. 2 (September 20, 2017): 287-303. Accessed November 12, 2020. https://ejournal.iainbengkulu.ac.id/index.php/Al-Intaj/article/view/2212.

Remi, Prof. Dr. Sutan Remy Sjahdeini, S.H. Perbankan Syariah: Produk-Produknya Dan AspekAspek Hukumnya. Jakarta: Kencana, 2014.

Sari, Sepri Wulan. “Perkembangan Dan Pemikiran Uang Dari Masa Ke Masa.” An-Nisbah: Jurnal Ekonomi Syariah 3, no. 1 (2016).

Suma, Muhammad Amin. "Himpunan Undang-Undang Perdata Islam dan Peraturan Pelaksana Lainnya Di Negara Hukum Indonesia." Jakarta: PT. Raja Grafindo Persada Press, 2008.

Susanti, Ressi. "Sejarah Transformasi Uang Dalam Islam." Aqlam: Journal of Islam and Plurality 2, no. 1 (February 1, 2018). Accessed November 10, 2020. http://journal.iain-manado.ac.id/ index.php/AJIP/article/view/509. 
ahmad ali sopian 